\title{
School-Based Needs Assessment of Teachers Development
}

\author{
Baiquni Rahmat \\ Department of Educational Management \\ Universitas Negeri Yogyakarta \\ Yogyakarta, Indonesia \\ baiquni@uny.ac.id
}

\begin{abstract}
Nowadays, management of secondary education in Indonesia is carried out based on the minimum service standards with the use of school-based management principles. School administrators were authorized to make their own efforts to improve the school's quality by establishing a strategic plan called 'flagship program'. Regarding to the policy, Senior High School 6 Yogyakarta had such program called The Research School Program Therefore, the school communities especially teachers, have to directly contribute to attain- the program's goals. This study was conducted to explore the needs analysis of teachers training and development for The Research School Program in Senior High School 6 Yogyakarta. This study used the qualitative approach. The data were collected using interviews and document studies. The results found two kinds of needs analysis conducted by the school to identify teachers training and development needs. First, organizational analysis was carried out to recognize the needs of teachers training and development in scope of overall school. Second, personal analysis was performed to identify teachers who need training and development programs and their readiness to join the program.
\end{abstract}

Keywords- needs analysis, teachers development

\section{INTRODUCTION}

Nowadays, management of secondary education unit In Indonesia is done based on peer minimum service standard by using principles of school-based management. This is in accordance with the provisions set out in Law Number 20 Year 2003 article 51 paragraph (1) [1].

Manajemen Berbasis Sekolah (MBS) or School-Based Management is an institutional application management model which provides autonomy enlargement to school managers in integrating and empowering both resources; internal and external resources in aiming to achieve institutional purposes.

The MBS application contributes school managers to more flexible in doing various kinds of creativity in order to improve educational services in accordance with each school conditions. Moreover, school managers are also given an obligation to do any effort in order to improve quality and establish a strategic plan which can be in a form of flagship program or featured program which is unique and not owned by other schools.

The accomplishment of schools in achieving a strategic plan is definitely influenced by several factors. One of the factors is teachers' quality and commitment. Teachers as one of the human resources who have a strategic role in the implementation of school development programs should be managed effectively and efficiently. Teachers' spirit, insight, and ability should always be improved so that they can contribute positively toward school development programs.

\section{RESEARCH METHOD}

\section{A. Research Type}

This research was a descriptive-qualitative research.

\section{B. Location and Time of the Research}

This research was done in Senior High School 6 Yogyakarta which is located at C. Simanjuntak, Number 2, Yogyakarta.

The initial study was done on September 2012 to October 2012, while the main study was done on January 2013 to April 2013.

\section{Subject of the Study}

The technique of determining the subject used in this research was purposive technique because of certain considerations. One of the considerations was a view that someone is perceived to be the most understanding of what is to be studied, or someone is a party who has the authority and strength so that it can facilitate or support the researcher in assessing the object or situation under study. The subject in this research consisted of some informants; a school principal, a vice principal of research and development affairs, two teachers, and the chairman of the committee of Senior High School 6 Yogyakarta.

\section{Instruments and Techniques of Data Collection}

The data collection activities carried out in this research used two data collection techniques, namely interview and document study.

The interview technique in this research was addressed to a school principal, a vice principal of research and development affairs, two teachers, and the chairman of the committee of Senior High School 6 Yogyakarta in order to obtain the data related to the teacher development management in the research program at Senior High School 6 Yogyakarta including the determination of needs, planning, execution, as well as 
supervision and evaluation of teacher development. Other than that, the interview was also done in order to gain the information related to the supporting factors as well as the inhibiting factors in teacher development management in research program at Senior High School 6 Yogyakarta. The document study was conducted on documents which obtained in this study, such as school profile, school organizational structure, and the teacher development activities proposal in research program at Senior High School 6 Yogyakarta.

\section{E. Data Analysis}

In this study, Miles and Huberman's interactive model was employed in the analysis of the data. The steps of the data analysis were as follows: collecting the data, reducing the data (Data Reduction), displaying the data, and drawing the conclusion [2].

\section{LITERATURE REVIEW}

Mondy, Noe, and Premeaux argued that training and human resource development is a planned and sustained effort of management to improve employee competency and organizational performance [3]. This opinion emphasizes the development of human resources in an organization which must be done systematically and continuously in order to improve organizational performance. In the context of the school as an organization, teacher training and development also must be implemented properly and sustainably. In addition, schools should not only wait and depend on government programs to train and develop teachers' competencies.

Related to the use and comparison of terms between training and development, Mondy, Noe, and Premeaux stated that although the terms training and development are often used interchangeably, a distinction is sometimes made between the two terms. Training is defined as an activity designed to provide the knowledge and skills needed to carry out work and tasks in the present. On the other hand, development is an activity involving learning about things that are wider and deeper than present work needs. This activity has more attention or long term [3].

Related to the objectives of human resource training and development, the objectives of human resource training and development in an organization are including 1) increasing the awakening of the soul and ideology, 2) increasing work productivity, 3) improving the quality of work, 4) improving the provision of human resource planning, 5) improving the moral attitude and work passion, 6) improving occupational health and safety, 8) avoiding obsolescence, and 9) increasing employees' personal development [4].

According to Noe, there are seven stages on human resources training and development. All of the stages are including assess the training needs, ensure the readiness of personnel in training, create a learning environment, ensure support for training programs, both from trainees, colleagues, as well as from the trainees' leaders, develop an evaluation plan, choose the training method, and monitor and evaluate the training programs [5].
On determining the human resources training and development needs, there are three parties that involved in identifying training and development needs. The first party is organizational unit which manages the human resources. The role of this work unit is to identify the needs of the organization as a whole, both for the present and for the organization to face the future challenges. The second party is the managers of various work units. As they are who lead everyday employees and they are also the ones who are most responsible for the success or failure of the units they lead. They are the ones who are most likely to know what training and development needs are needed. The third party is the employees themselves. Many organizations give employees the opportunity to nominate themselves for specific training and development programs. The starting point of this opportunity is that intellectually mature employees know the weaknesses that remain within each other [6].

Meanwhile, Delahaye argued that there are four stages in human resource development, namely the investigation stage, the design stage, the implementation stage, and the evaluation stage [7].

In addition, Delahaye proposed another term related to the assessment of needs in human resource development, namely Human Resource Development Needs Investigation (HRDNI). According to Delahaye, "... HRDNI is a process that identifies the gap between what is currently happening and what should be occurring". This view means that HRDNI (needs assessment) is a process that identifies the gap between what is going on and what is supposed to happen.

The HRDNI seeks answers to such underlying topics as:

- The content and learning objectives - What is going well? What needs improvement? What content needs to be covered? What examples are there of good practice? What examples are there of bad practice? How can this content be categorized - is it explicit or tacit knowledge; is it to do with the frames of reference of learners? Are we seeing cause-and-effect or do the variables under investigation merely have a correlational relationship?

- The population - Who needs to be developed, what are their levels of knowledge, skills and abilities? Are there groups of potential learners or is the issue more individually based? How motivated are they? How do they prefer to learn?

- $\quad$ The resources needed - What resources are needed to conduct the learning experience? What resources are available? What is the overall time frame within which the development should be achieved? What has to occur first, what second and so on?

- The context and organizational politics - What are the organizational political ramifications of the issue under investigation? Who is likely to support it? Who besides the learner will benefit? Who is likely to feel threatened by the outcomes of the learning? What are the opinions of the key stakeholders - do they want the learners to be highly proficient or will a coping 
level be accepted? What level and type of resources are the key decision makers willing to invest in the learning outcomes? [7].

\section{FINDINGS AND DISCUSSION}

The result of the research shows that Senior High School 6 Yogyakarta performed two types of analysis of teacher development needs, namely organizational analysis and personal analysis. With regard to organizational analysis, school implements it by referring to the school's strategic plan, like the school's featured program such as environmentally sound school, research school and cultural school. Senior High School 6 Yogyakarta considered that the school needs to carry out its teacher development activities in the field of research to support the work program of Senior High School 6 Yogyakarta as Research-Based School. The school considered that teachers who are proficient in the field of research, both in terms of conducting research and integrating the values of research into learning for learners is a very potential factor to support the success of the implementation of Research-Based School program at Senior High School 6 Yogyakarta. In addition, the development of teachers of Senior High School 6 Yogyakarta was also done to improve the research ability for teachers so that they can conduct professional development through researches, such as classroom action research.

This means that in determining teacher development needs, the school considered the vision and mission of Senior High School 6 Yogyakarta as the foundation for organizing teacher development activities. Senior High School 6 Yogyakarta has the belief that teacher development activities in the field of research needed to be implemented to support the SchoolBased Research program in the school.

These were in accordance with the concept of organizational analysis in determining teacher development needs proposed by Noe that argues that organizational analysis includes identifying the contribution of training and development programs in support of the organization's strategic direction, the managers, colleagues, and employees' support for the implementation of training and development programs, as well as the availability of resources to organize training and development programs. Besides, it is also in line with Torrington, Hall, and Taylor's opinion that the HR development strategy should focus on the organization's goals and targets and identify the skills and competencies required to achieve them [8].

The effort that was taken by Senior High School 6 Yogyakarta to determine the needs of teacher development was by monitoring and evaluating teachers' weaknesses and strength in the field of research. Monitoring and evaluating activities were carried out informally, i.e. through daily conversation. The vice principal of research and development affairs openly received input from teachers related to the teacher development. Based on conversations with teachers, he identified teachers' weaknesses and strength in terms of research. The results of identification were used as a consideration for conducting teacher development activities.

These were in accordance with the concept of personal analysis suggested by Noe which states that person analysis helps to identify who needs training, that is, whether current performance or expected performance indicators need for training. The statement means that personal analysis can help to identify who is deemed necessary to attend training and development programs. In addition, personal analysis also examined the readiness of employees to attend training and development programs.

Teachers' readiness to follow the development activities was influenced by factors that are internal and external. Referring to Noe's opinion, in which these factors were concerned with (1) whether the teachers have the personal characteristics (abilities, attitudes, beliefs, and motivations) necessary to learn the training and development materials and apply them to the work or not, and (2) whether the existing work environment will facilitate the learning process and does not interfere with the performance of the organization.

\section{CONCLUSIONS}

The development and enhancement of teachers' spirit, insight, and ability should be well implemented in each stage. Those stages are including determining needs, objectives and training materials, budgeting, trainers management, determining training methods, implementing training programs, and supervising and evaluating training programs. Therefore, good management is needed so that the purpose of development activities can be achieved effectively and efficiently.

The determination of teacher development needs should be carried out on the basis of analysis results; organizational analysis, personal analysis, and task analysis. Organizational analysis is conducted in several ways to know some outputs like the benefits of development activities in support of strategic plans and development of resources for its own development activities. As for personal analysis is aimed to identify teachers who are considered necessary to attend training and development programs. Meanwhile, task analysis is performed to find work details for each teacher and the competencies required to carry out the work.

In addition, in teacher development management, it is also required supervision and evaluation. Supervision is undertaken to ensure that teacher development activities are carried out in accordance with the plan as well as consideration for corrective action when there are matters in the implementation of development that are not in accordance with the plan. The evaluation is done to know the achievement of targets set in the plan as well as consideration to improve the next teacher development activities quality.

\section{REFERENCES}

[1] Act of Republic of Indonesia Number 20/2003

[2] Miles \& Huberman, "Qualitative data analysis; an expanded sourcebook $\left(2^{\text {nd }}\right.$ ed.)". London: Sage Publication, 1994.

[3] Mondy, R.W., Noe, R.M., \& Premeaux, S.R., "Human resource management ( $7^{\text {th }}$ ed.)". New Jersey: Prentice Hall, Inc., 1999.

[4] Anwar Prabu Mangkunegara, "Perencanaan dan pengembangan sumber daya manusia". Bandung: P.T. Refika Aditama, 2006.

[5] Noe, R.A., "Employee training and development". New York: McGrawHill Companies, 2005. 
[6] Siagian, Sondang P., "Manajemen sumber daya manusia". Jakarta: Bumi Aksara, 2011

[7] Delahaye, B., "Human resource development: managing learning and knowledge capital ( $3^{\text {rd }}$ ed.)". Prahran: Tilde University Press, 2011.
[8] Torrington, D., Hall, L., and Taylor, S., "Human Resources Management ( $7^{\text {th }}$ edition)". Essex: Pearson Education Limited, 2008. 